\title{
Diagnostic pitfalls in neuromyelitis optica spectrum disorders
}

\section{Pułapki diagnostyczne w chorobach z kręgu neuromyelitis optica}

\author{
'Department of Neurology, Division of Neurochemistry and Neuropathology, Poznan University of Medical Sciences, Poznan, Poland \\ ${ }^{2}$ Department of Neurology, Poznan University of Medical Sciences, Poznan, Poland \\ Correspondence: Associate Professor Alicja Kalinowska-kyszzzarz, MD, PhD, Department of Neurochemistry and Neuropathology, Poznan University of Medical Sciences, \\ 49 Przybyszewskiego St., 60-355 Poznan, Poland, tel.. +48 61869 15 35, e-mail: akalinowskalyszzzarz@ump.edu.pl
}

\begin{abstract}
Neuromyelitis optica spectrum disorders are autoimmune disorders of the central nervous system marked by inflammatory demyelination, axonal loss and astrocytopathy, associated with lesions in the brain and in the spinal cord and with the presence of antibodies against aquaporin 4 (AQP4-IgG). Various studies on neuromyelitis optica spectrum disorders broaden the knowledge about their immunopathogenesis, clinical course, immunological assays, and magnetic resonance imaging findings. Nevertheless, in clinical practice differential diagnosis remains challenging, particularly in cases seronegative for AQP4-IgG. Essential clinical syndromes in neuromyelitis optica spectrum disorders, namely optic neuritis and acute myelitis, could also be observed in multiple sclerosis and other demyelinating diseases of the central nervous system. The early and accurate diagnosis is essential due to different prognosis and treatment strategies in these diseases. For example, therapies used in multiple sclerosis, including beta-interferons, natalizumab, fingolimod and alemtuzumab, may not only be ineffective in neuromyelitis optica spectrum disorders but even harmful and provoke relapses. Therefore, in a patient with a clinical neurological syndrome accompanied by demyelinating lesions in the central nervous system several investigative studies should be undertaken, including serological assays [AQP4-IgG, antibodies against myelin oligodendrocyte glycoprotein (MOG-Ab)], the cerebrospinal fluid examination and magnetic resonance imaging of the brain and spinal cord, and interpreted with caution. Due to clinical similarities and relatively common misdiagnoses, there is a need to summarise the typical and atypical clinical, laboratory and radiographic features in neuromyelitis optica spectrum disorders to avoid diagnostic pitfalls and inappropriate treatment.
\end{abstract}

Keywords: neuromyelitis optica spectrum disorders, multiple sclerosis, demyelinating diseases, antibodies against aquaporin 4, antibodies against myelin oligodendrocyte glycoprotein

StreszCzenie Choroby z kręgu zapalenia nerwów wzrokowych i rdzenia kręgowego (spektrum neuromyelitis optica, spektrum NMO) to autoimmunologiczne schorzenia ośrodkowego układu nerwowego charakteryzujące się zapalną demielinizacją, utratą aksonów oraz astrocytopatią, z towarzyszącymi ogniskami patologicznymi w mózgu i w rdzeniu kręgowym oraz z obecnością przeciwciał przeciwko akwaporynie 4 (AQP4-IgG). Rozmaite badania and chorobami z kręgu zapalenia nerwów wzrokowych i rdzenia kręgowego poszerzyły wiedzę na temat ich immunopatogenezy, przebiegu klinicznego, badań immunologicznych oraz nieprawidłowości w obrazach rezonansu magnetycznego. Jednakże w praktyce klinicznej rozpoznanie różnicowe pozostaje wyzwaniem, zwłaszcza w przypadkach seronegatywnych w zakresie AQP4-IgG. Najważniejsze zespoły kliniczne w chorobach ze spektrum NMO, czyli zapalenie nerwu wzrokowego oraz ostre zapalenie rdzenia, obserwuje się również w stwardnieniu rozsianym oraz innych chorobach demielinizacyjnych ośrodkowego układu nerwowego. Wczesna i prawidłowa diagnoza ma kluczowe znaczenie ze względu na odmienne rokowanie oraz strategie terapeutyczne w tych schorzeniach. Na przykład terapie stosowane w stwardnieniu rozsianym, w tym interferony beta, natalizumab, fingolimod oraz alemtuzumab, mogą być nie tylko nieskuteczne w chorobach ze spektrum NMO, ale nawet szkodliwe i powodować zaostrzenie choroby. Dlatego też pacjenci z klinicznym zespołem objawów neurologicznych z towarzyszącymi zmianami demielinizacyjnymi w ośrodkowym układzie nerwowym powinni przejść szereg badań diagnostycznych, z uwzględnieniem badań serologicznych [AQP4-IgG, przeciwciała przeciwko mielinowemu białku oligodendrocytów (MOG-Ab)], analizy płynu mózgowo-rdzeniowego oraz rezonansu magnetycznego mózgu i rdzenia kręgowego, a ich wyniki należy interpretować z należytą ostrożnością. Ze względu na podobieństwa kliniczne oraz stosunkowo częste błędne rozpoznania istnieje potrzeba podsumowania typowych i nietypowych klinicznych, laboratoryjnych oraz radiologicznych cech chorób ze spektrum NMO, aby unikać pomyłek diagnostycznych oraz niewłaściwego leczenia.

Słowa kluczowe: choroby z kręgu zapalenia nerwów wzrokowych i rdzenia kręgowego (spektrum NMO), stwardnienie rozsiane, choroby demielinizacyjne, przeciwciała przeciwko akwaporynie 4, przeciwciała przeciwko mielinowemu białku oligodendrocytów 


\section{INTRODUCTION}

$\mathrm{N}$ euromyelitis optica spectrum disorders (NMOsd), previously known as Devic disease, are autoimmune inflammatory disorders of the central nervous system (CNS) associated with astrocytic pathology, severe demyelination and axonal damage, classically characterised by optic neuritis (ON) and transverse myelitis attacks as well as seropositivity for antibodies against aquaporin 4 (AQP4-IgG) in the majority of cases (Wingerchuk, 2010; Wingerchuk et al., 2007). Despite distinct pathogenesis, clinical course, laboratory and magnetic resonance imaging (MRI) findings, in clinical practice NMOsd, particularly AQP4-IgG seronegative, may by confounded with multiple sclerosis (MS) and other CNS demyelinating diseases, or mimic their clinical features (Juryńczyk et al., 2021; Kim et al., 2017).

The differences between NMOsd and other causes of CNS demyelination as well as the risk of misdiagnoses became a subject of various publications. Avasarala et al. (2020) showed that $0.62 \%$ of NMOsd patients from the Truven Health Analytics (THA) database and 7.4\% from their own database were diagnosed as NMOsd after initial MS diagnosis. They concluded that testing for NMOsd, including screening for AQP4-IgG and antibodies against myelin oligodendrocyte glycoprotein (MOG- $\mathrm{Ab}$ ), should be mandatory prior to MS diagnosis, even in cases with clinical and radiological features typical for MS. Moreover, retesting towards NMOsd may be necessary in some cases depending on the response to disease modifying treatment (DMT) (Avasarala et al., 2020). In a study by Juryńczyk et al. (2016) 27 neurology consultants were asked for diagnosis in patients with overlapping clinical features of seronegative NMOsd and MS. The most common answers included NMOsd and MS, but also other alternatives appeared including: idiopathic longitudinally extensive transverse myelitis (LETM), relapsing isolated optic neuritis (RION), chronic relapsing inflammatory optic neuritis (CRION), acute disseminated encephalomyelitis (ADEM), and rarely: recurrent transverse myelitis, neurosarcoidosis, vasculitis, Leber hereditary neuropathy, antiphospholipid syndrome (APLS) or systemic lupus erythematosus (SLE) (Juryńczyk et al., 2016). Although AQP4-IgG seronegative NMOsd is particularly challenging in everyday clinical practice, in seropositive cases pitfalls could also occur. For instance, Solomon et al. (2016) observed that in 110 misdiagnosed MS patients 7 (6\%) had NMOsd, including 5 AQP4-IgG seropositive cases.

For many years neuromyelitis optica (NMO) was diagnosed based on the 2006 revised criteria (Tab. 1) (Wingerchuk et al., 2006). Subsequently, other limited forms of the disease including recurrent $\mathrm{ON}$, recurrent myelitis and some typical brain syndromes with AQP4-IgG seropositivity were recognised as NMOsd (Wingerchuk, 2010). The "International consensus diagnostic criteria for neuromyelitis optica spectrum disorders" from 2015 introduced the general term of NMOsd divided into cases with or without AQP4-IgG based on the results of serological testing. Importantly, the new criteria include not only episodes of $\mathrm{ON}$ or acute myelitis, but also other core clinical syndromes as well as several defined NMOsd-specific MRI lesion patterns essential for the diagnosis (Tab. 1) (Wingerchuk et al., 2015). Applying the 2015 NMOsd criteria in the cohort of patients with a clinical syndrome with CNS demyelination atypical for MS resulted in the increase in NMOsd diagnosis by $76 \%$. It was particularly high in AQP4-IgG seropositive patients in comparison with seronegative cases (62\% and $14 \%$, respectively) (Hamid et al., 2017). On the other hand, when compared with $2006 \mathrm{NMO}$ and 2007 NMOsd criteria, the rise in sensitivity of 2015 criteria would be lower (giving the increase of NMOsd cases by 5.1\%) (Wingerchuk and Weinshenker, 2017).

\begin{tabular}{|c|c|c|}
\hline \multirow{3}{*}{$\begin{array}{l}\text { The revised diagnostic criteria for NMO (2006) } \\
\text { - ON } \\
\text { - Acute myelitis } \\
\text { - At least } 2 \text { of } 3 \text { supportive criteria: spinal cord MRI } \\
\text { lesions encompassing } \geq 3 \text { continuous vertebral } \\
\text { segments, brain MRI not fulfilling MS diagnostic } \\
\text { criteria, seropositivity for AQP4-IgG }\end{array}$} & \multicolumn{2}{|c|}{ The international consensus diagnostic criteria for NMOsd (2015) } \\
\hline & NMOsd with AQP4-IgG & NMOsd without AQP4-IgG \\
\hline & $\begin{array}{l}\text { - } \geq 1 \text { core clinical syndrome } \\
\text { - AQP4-lgG seropositivity } \\
\text { (CBA recommended) } \\
\text { - Exclusion of other diagnoses }\end{array}$ & $\begin{array}{l}\text { - } \geq 2 \text { core clinical syndromes coming from } \geq 1 \text { clinical attack } \\
\text { and meeting all undermentioned conditions: } \\
\text { - opresence } \geq 1 \text { of } 3 \text { core clinical syndromes: } 0 N \text {, acute myelitis } \\
\text { with LETM, area postrema syndrome } \\
\text { o dissemination in space: presence } \geq 2 \text { core clinical syndromes } \\
\text { - fulfilled additional MRI requirements } \\
\text { - AQP4-IgG seronegativity/testing unavailable } \\
\text { - Exclusion of other diagnoses }\end{array}$ \\
\hline & $\begin{array}{l}\text { Core clinical syndromes: } \\
\text { - ON } \\
\text { - Acute myelitis } \\
\text { - Area postrema syndrome } \\
\text { - Acute brainstem syndrome } \\
\text { - Symptomatic narcolepsy or acute } \\
\text { diencephalic syndrome with } \\
\text { NMOsd-typical diencephalic MRI lesions } \\
\text { - Symptomatic cerebral syndrome with } \\
\text { NMOsd-typical brain lesions }\end{array}$ & $\begin{array}{l}\text { Additional MRI requirements for AQP4-IgG seronegative NMOsd: } \\
\text { - Acute ON: normal brain MRI or nonspecific white matter lesions; } \\
\text { OR T2-hiperintense or T1-Gd (+) lesion encompassing }>1 / 2 \text { optic } \\
\text { nerve length or including optic chiasm } \\
\text { - Acute myelitis: spinal cord lesion } \geq 3 \text { continuous vertebral segments } \\
\text { (LETM); OR focal spinal cord atrophy } 3 \text { continuous vertebral segments } \\
\text { in patients with history of myelitis } \\
\text { - Area postrema syndrome: lesion in dorsal medulla/area postrema } \\
\text { - Acute brainstem syndrome: periependymal brainstem lesion }\end{array}$ \\
\hline & & \\
\hline
\end{tabular}


The above-mentioned data showed that differential diagnosis between NMOsd and various demyelinating diseases of the CNS remains challenging, even with such a specific biomarker as AQP4-IgG, but it is essential due to a different prognosis and therapeutic approach (Selmaj and Selmaj, 2019). For example, therapies used in MS, particularly betainterferons, natalizumab, fingolimod and alemtuzumab, are ineffective or may even provoke deterioration in NMOsd patients (Gelfand et al., 2014; Juryńczyk et al., 2015). Therefore, there is a need to summarise and distribute the knowledge about typical and atypical findings in NMOsd to avoid diagnostic pitfalls, including differences among clinical features, laboratory testing and demyelinating lesions' pattern on MRI of the brain and spinal cord.

\section{CLINICAL PITFALLS}

NMOsd onset occurs typically around the age of 40 and it has a relapsing course in $80-90 \%$ of cases, but rarely a monophasic disease might also occur (Fig. 1) (Wingerchuk, 2010; Wingerchuk et al., 2007). Several clinical manifestations of NMOsd (Tab. 2) could also be observed in MS and other demyelinating diseases. Establishing an accurate diagnosis could be challenging in patients with $\mathrm{ON}$, acute myelitis and brainstem syndrome, particularly at the disease onset and in AQP4-IgG seronegative cases (Juryńczyk et al., 2015).

$\mathrm{ON}$ is one of the key manifestations of NMOsd and could be unilateral or bilateral (20\% of AQP4-IgG seropositive cases) (Juryńczyk et al., 2015). In NMOsd ON attacks are more severe in comparison with MS and have limited recovery. Other features of NMOsd-ON include the optic chiasm involvement and abnormalities in the retinal vessels like peripapillary attenuation or focal narrowing of arteries (Wingerchuk, 2010).

Optical coherence tomography (OCT) and visual evoked potentials (VEP) could facilitate differential diagnosis. In comparison with $\mathrm{MS}, \mathrm{ON}$ in NMOsd leads to more severe axonal damage and thinning of the retinal nerve fibre layer (RNFL) with predilection to the superior and inferior quadrants (Bichuetti et al., 2013; Naismith et al., 2009). It was observed that RNFL loss $>15 \mu \mathrm{m}$ should prompt NMOsd diagnosis and RNFL of $41 \mu \mathrm{m}$ is $100 \%$ specific for NMOsd and CRION (Bichuetti et al., 2013). VEP could be normal in NMOsd patients (13.2\% eyes examined) or show absence of response (47.4\%) and/or P100 wave amplitude reduction with normal latency (34.2\%). However, rarely (5.3\%) abnormalities typical for MS might be present, including delayed P100 latency with a normal amplitude (which is found in $60-100 \%$ of MS patients) (Neto et al., 2013).
LETM is another essential syndrome in NMOsd with relapses manifested by the lower limbs paresis, abnormal sensation and bladder or bowel disturbances. Accompanying symptoms include: Lhermitte sign, neuropathic pain and paroxysmal tonic spasms (40\% of patients) (Wingerchuk, 2010). In case of cervical myelitis rostral extension of the lesion into brainstem could occur and result in respiratory failure that is a potential cause of death (Wingerchuk, 2010; Wingerchuk et al., 2007).

Another typical manifestation is area postrema syndrome with intractable hiccups, nausea and vomiting, which result from the lesion in periaqueductal region of the brainstem called area postrema or in the nucleus tractus solitarius (Wingerchuk, 2010).

Less common core clinical syndromes in NMOsd include: brainstem syndrome, narcolepsy, diencephalic and cerebral syndrome (Wingerchuk, 2010), which should be associated with a confirmed lesion on the brain MRI in particular, corresponding anatomic regions, even in AQP4-IgG seropositive cases (Wingerchuk et al., 2015).

In unequivocal cases careful clinical observation is necessary. ON and myelitis relapses appear rather sequentially than simultaneously and could be separated by various time periods, even years (Wingerchuk et al., 2007). In comparison with MS, in NMOsd the clinical course is typically more severe, recovery from relapses incomplete, the prognosis worse and there is no progressive phase. It was showed that after 5 years of disease duration unilateral blindness was present in $41 \%$ and bilateral in 9\% of AQP4-IgG-seropositive NMOsd patients; while in MS 77\% of patients had a visual acuity of at least 6/6 after 15 years (Juryńczyk et al., 2015). On the other hand, cases of NMOsd with a mild clinical course occur (Kim et al., 2017). Therefore, clinical observation of disease course could be helpful, but is not always conclusive.

\section{LABORATORY PITFALLS}

\section{Antibodies against aquaporin 4}

AQP4-IgG are a specific marker of NMOsd with 73\% sensitivity and $91 \%$ specificity and a crucial element of the disease immunopathogenesis (Wingerchuk, 2010). Nevertheless, sensitivity of AQP4-IgG depends on various factors, which should be remembered to avoid diagnostic pitfalls (Fig. 2).

Firstly, various methods of AQP4-IgG detection are available and vary in sensitivity, which is the highest for cellbased assays (CBA) recommended according to the 2015

\begin{tabular}{|l|l|l|}
\hline Most common & Less common & Rare/unusual \\
\hline - Optic neuritis & - Brainstem syndrome & - Endocrinopathies \\
- Acute myelitis & - Narcolepsy & - Encephalopathy \\
- Area postrema syndrome & $\begin{array}{l}\text { - Diencephalic syndrome } \\
\text { - Cerebral syndrome }\end{array}$ & \begin{tabular}{l} 
C Posterior reversible encephalopathy syndrome (PRES) \\
\hline
\end{tabular}
\end{tabular}

Tab. 2. Clinical manifestations of NMOsd 


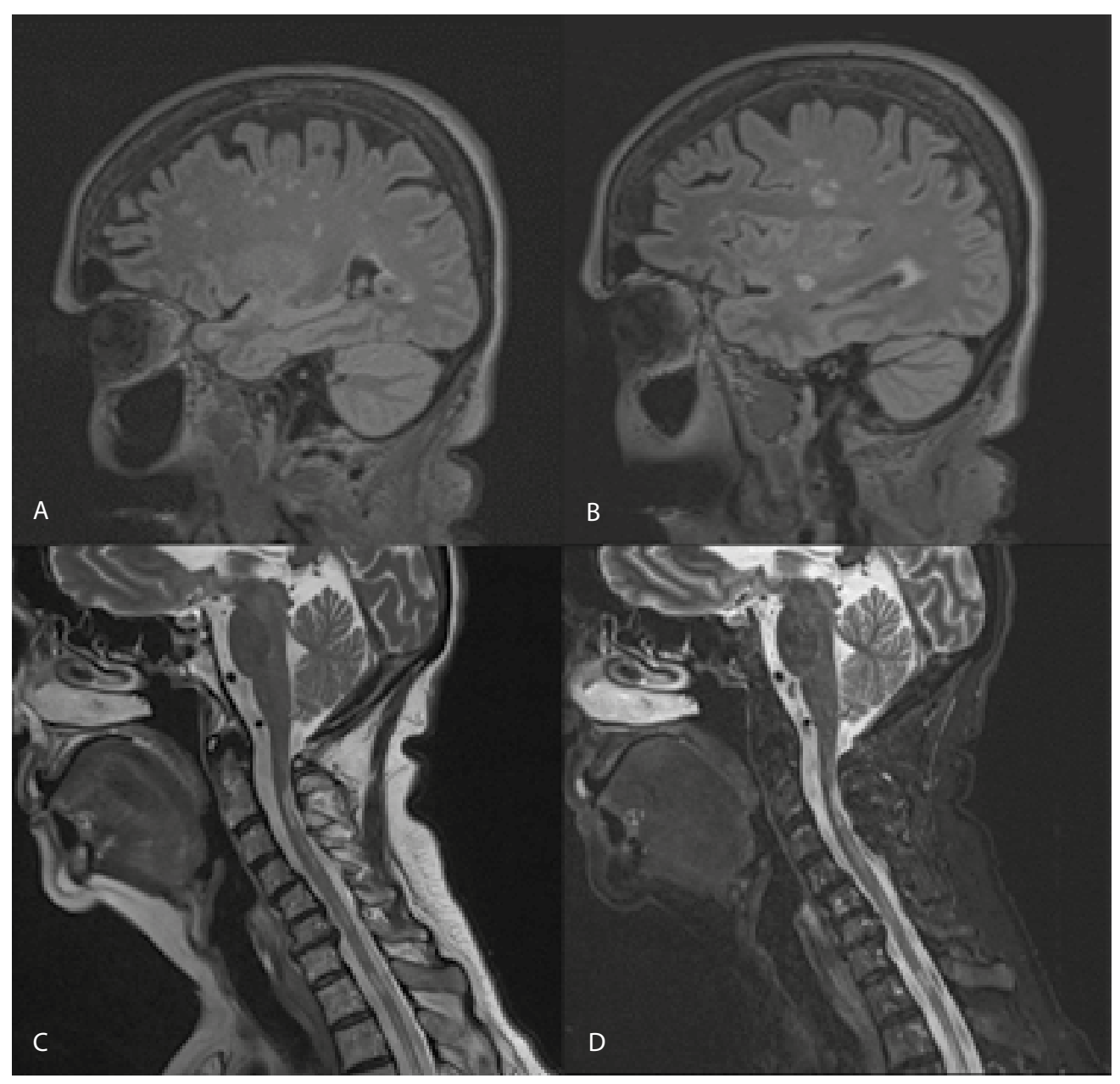

Fig. 1. 3T-MRI of the brain (A, B) and the spinal cord (C, D) in a 77-year-old woman with NMOsd.

Case history: at the age of 68 she presented several episodes of $O N$, which partially improved after steroid treatment. At the age of 70 she presented the left lower limb weakness, which was treated with steroids with poor recovery. Her first MRI revealed a central, longitudinal spinal cord lesion extending between C7 and Th5/Th6 level, which was T2-hyperintense and T1-hypointense with inhomogeneous gadolinium-enhancement and spinal cord swelling. CSF examination detected $13 \mathrm{WBC} / \mu \mathrm{L}$ and the protein level of $374 \mathrm{mg} / \mathrm{L} ; \mathrm{IgG}$ index was 0.48 and OCBs were present in the CSF but absent in the serum. AQP4-IgG was positive and the diagnosis of NMOsd was reached. Brain MRI showed multiple T2-hyperintense lesions not typical for MS. Follow-up MRI of the spinal cord revealed intramedullary T2-hyperintense confluent lesions at the levels of C1-C7 and multiple lesions in the thoracic spinal cord. Subsequently, the patient experienced several relapses manifesting as ON, lower and/or upper limbs weakness, impaired sensation on the trunk and limbs. The disease attacks were treated with methylprednisolone intravenously with partial improvement. There was an attempt of treatment with plasma exchanges and intravenous immunoglobulins, but due to poor PLEX tolerance and low IgA levels they were not repeated. She was given oral steroids and add-on azathioprine as maintenance therapy. Subsequent last available 3T-MRI showed: (A, B) multiple FLAIR-hyperintense lesions; (C, D) numerous T2-hyperintense lesions located posteriorly in the cervical and thoracic spinal cord. At that time her EDSS was 7.5.

Diagnostic pitfall: the patient had a late onset of the disease which typically occurs in the fourth decade.

Abbreviations: AQP4-IgG - antibodies against aquaporin 4; CSF - cerebrospinal fluid; EDSS - Expanded Disability Status Scale; MRI - magnetic resonance imaging; MS - multiple sclerosis; NMOsd - neuromyelitis optica spectrum disorder; OCBs - oligoclonal bands; PLEX - plasma exchange; WBC - white blood cells 


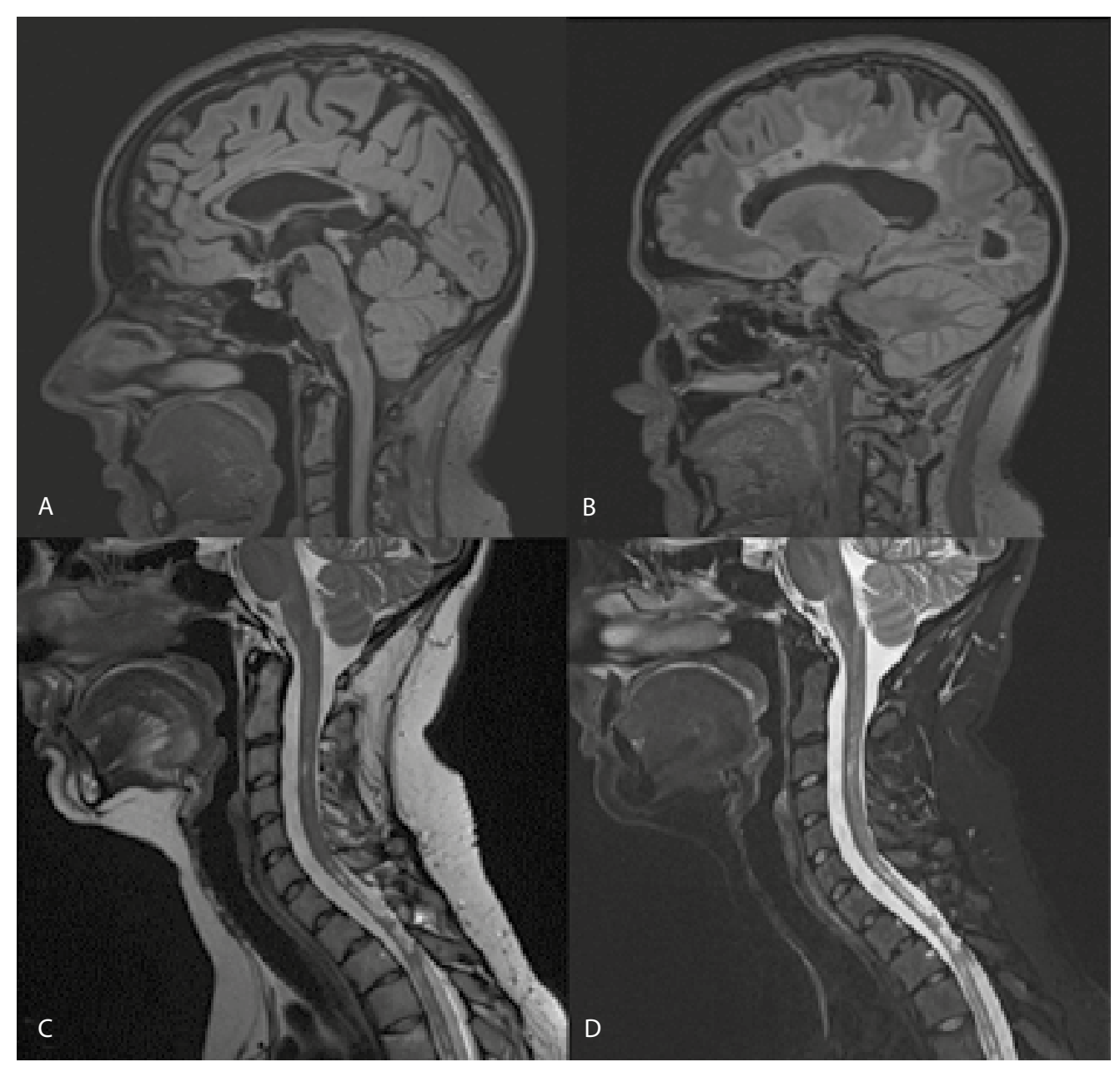

Fig. 2. 3T-MRI of the brain (A, B) and the spinal cord (C, D) in a 26-year-old woman with NMOsd.

Case history: the disease onset in 2002, at the age of 11, manifested as the lower limbs weakness with pathological signs and impaired sensation below the level of Th6-Th7 and with an intramedullary C3-Th5 lesion with the spinal cord enlargement and irregular gadoliniumenhancement, which led to the suspicion of an intramedullary tumour, but biopsy revealed inflammatory demyelination. The diagnosis of cervical and thoracic myelitis was made and oral steroids applied. Two years later her MRI showed disseminated T2-hyperintense brain lesions without gadolinium-enhancement of unclear aetiology and intramedullary T2-hyperintense lesions in the cervical and the thoracic spinal cord with discrete gadolinium-enhancement. CSF examination revealed 2-3 WBC/ $\mu \mathrm{L}$ and protein level of $26 \mathrm{mg} / \mathrm{dL}$; IgG index was 0.73 and OCBs were present in the CSF. Disseminated encephalitis was diagnosed and intravenous methylprednisolone with subsequent oral steroids were applied. Due to young age and partial regression of abnormalities, particularly in the brain on follow-up MRI, ADEM was suspected. Subsequently, the patient experienced several events of the right lower limb weakness with impaired sensation, each time treated with intravenous or oral methylprednisolone. At the age of 14, the diagnosis of multiple sclerosis was proposed. Due to the local MS treatment rules in Poland and given MS drug labels, the patient was initiated on beta-interferon three years later, at the age of 17, and after 1 year she was switched to glatiramer acetate. During the following years she presented several disease attacks, including ON, lower limbs weakness with bladder dysfunction, abnormal sensation on the trunk or lower limbs. At the of age 20 the episode of simultaneous bilateral ON and acute myelitis occurred. Brain MRI revealed multiple diffuse demyelinating plaques with gadolinium-enhancement of the lesions in the corpus callosum and those located periventricularly, and T2-hyperintense, T1-hypointense irregular, intramedullary longitudinally extensive lesions throughout the thoracic spinal cord with gadolinium-enhancement. At that time the patient's test for AQP4-IgG was positive and the diagnosis of NMOsd was reached 8 years after the disease onset. The patient was treated with plasma exchanges and intravenous methylprednisolone with partial improvement. Subsequent most recent 3T-MRI showed: (A, B) multiple, confluent FLAIR-hyperintense lesions with cavitation and corpus callosum atrophy; (C, D) numerous T2-hyperintense lesions in the cervical and thoracic spinal cord with atrophy in thoracic region. At that time her EDSS was 6.5 .

Diagnostic pitfall: when the patient was being diagnosed for her first symptoms AQP4-IgG testing was not available and NMOsd diagnosis was based on the simultaneous presence of ON and myelitis. Also, at that time neither MS nor NMOsd were considered to be common in children. Therefore, ADEM was considered as a diagnostic possibility.

Abbreviations: ADEM - acute disseminated encephalomyelitis; AQP4-IgG - antibodies against aquaporin 4; CSF - cerebrospinal fluid; EDSS - Expanded Disability Status Scale; MRI - magnetic resonance imaging; MS - multiple sclerosis; NMOsd - neuromyelitis optica spectrum disorder; $\boldsymbol{O C B s}$ - oligoclonal bands; $\mathbf{W B C}$ - white blood cells 
criteria (Waters and Vincent, 2008; Wingerchuk et al., 2015). CBA are believed to have $91 \%$ sensitivity and $100 \%$ specificity. Indirect immunofluorescence (IIF), which was the original method of AQP4-IgG identification, and enzyme-linked immunosorbent assay (ELISA), have lower sensitivity (54-73\% and $71 \%$, respectively) as well as specificity (94-100\% and 98\%, respectively) (Waters and Vincent, 2008). Nevertheless, if CBA is unavailable, the 2015 criteria allow the use of IIF and ELISA, but point to the necessity of careful interpretation of the results, particularly in cases with low AQP4-IgG titres measured by ELISA (Wingerchuk et al., 2015).

Secondly, timing of the blood sample collection is crucial, as serum levels of AQP4-IgG depend on disease activity (relapse vs. remission) and treatment status (i.e. following steroid treatment) (Takahashi et al., 2007). AQP4-IgG serum levels increase by $124-294 \%$ (20\% per week) before disease deterioration and are significantly higher during relapse than in remission (Jarius et al., 2008). In turn, treatment with intravenous methylprednisolone (IVMP) leads to decrease of AQP4-IgG serum titres, which remain low during maintenance therapy with azathioprine with prednisolone, rituximab or cyclophosphamide (Jarius et al., 2008; Takahashi et al., 2007). Also, patients during or shortly after plasmapheresis could have lower serum AQP4-IgG levels (Takahashi et al., 2007). Therefore, blood sample for AQP4-IgG should be taken preferably during relapse and before starting any immune therapy to avoid false-negative results.

False-positive results of AQP4-IgG test occur relatively rarely, depending on the type of the assay (Waters and Vincent, 2008). Noteworthy, cases of false-positive AQP4-IgG results were reported in MS patients treated with natalizumab or with spinal arteriovenous fistula (Cohen et al., 2016; Suthiphosuwan et al., 2017).

Considering the above-mentioned facts and the possibility of the conversion from seronegativity to seropositivity, retesting for AQP4-IgG could be reasonable in patients without AQP4-IgG, who present NMOsd clinical features but do not fulfil the 2015 criteria for seronegative NMOsd, especially if they experience relapses (Wingerchuk et al., 2015). In these cases retesting with the most sensitive available method is recommended during disease relapse and in periods without treatment, 3-6 months after the previous assay (Waters et al., 2014).

Testing the cerebrospinal fluid (CSF) for AQP4-IgG is not routinely used in clinical practice and, according to the 2015 NMOsd criteria, it is not generally recommended

\begin{tabular}{|c|c|c|}
\hline Disease & MRI of the brain & MRI of the spinal cord \\
\hline NMOsd & $\begin{array}{l}\text { - Typical lesions location and characteristics: } \\
\text { o the dorsal brainstem: particularly lesions by the fourth ventricle and in area postrema; } \\
\text { often continuous with the cervical spinal cord lesion } \\
\text { o the diencephalon in adjacent to the third ventricle and aqueduct: lesions in the thalamus, } \\
\text { hypothalamus and midbrain } \\
\text { o the areas surrounding the lateral ventricles: lesions in the corpus callosum could be present } \\
\text { in 12-40\% of NMOsd cases; adjacent to the lateral ventricles or continuous with ependyma; } \\
\text { if acute, heterogenous or oedematous } \\
\text { o the cerebral hemispheres: typically extensive and confluent, tumefactive lesions } \\
\text { o the corticospinal tracts: uni- or bilateral lesions, confluent and longitudinally extensive } \\
\text { "Cloud-like" enhancing pattern } \\
\text { - MR spectroscopy: reduced myo-inositol in lesions }\end{array}$ & $\begin{array}{l}\text { - T2-hyperintense longitudinally extensive, } \\
\text { continuous lesions comprising } \geq 3 \text { vertebral } \\
\text { segments } \\
\text { - Central location with grey matter involvement } \\
\text { - Hypointensity on T1-weighted scans } \\
\text { - Gadolinium enhancement of the T1-weighted } \\
\text { lesion } \\
\text { - Longitudinally extensive spinal cord atrophy } \\
\text { extending over } \geq 3 \text { contiguous vertebral } \\
\text { segments in patients with history of myelitis }\end{array}$ \\
\hline MS & $\begin{array}{l}\text { - Hyperintense, ovoid, of various sizes (typically }>3 \mathrm{~mm} \text { ) lesions on T2-weighted scans } \\
\text { - Dawson fingers, S-shaped and U-fibre lesions } \\
\text { - Lesions around lateral ventricles and in temporal lobes } \\
\text { - Cortical lesions } \\
\text { - hypointense lesions ("black holes") on T1-wieghted scans } \\
\text { - Ovoid or ring/open-ring enhancing pattern } \\
\text { - Brain atrophy (cortical - primary progressive MS, periventricular - relapsing-remitting MS) } \\
\text { - MR spectroscopy: decreased N-acetylaspartate }\end{array}$ & $\begin{array}{l}\text { - Short (1-2 segments), usually numerous lesions } \\
\text { - Peripheral/asymmetrical/posterior location } \\
\text { - Rarely hypointensity on T1-weighted images }\end{array}$ \\
\hline ADEM & $\begin{array}{l}\text { - Polyfocal, bilateral, asymmetric, ill-defined and different-size lesions } \\
\text { - Location: subcortical/central white matter, basal ganglia, thalami, cerebellum, brainstem } \\
\text { - Typical: periventricular sparing and absence of Dawson fingers } \\
\text { - Gadolinium enhancement in up to } 30 \% \text { of patients } \\
\text { - Lack of "black holes" on T1-weighted scans } \\
\text { - Follow-up MRI: partial/complete resolution and lack of new lesions }\end{array}$ & $\begin{array}{l}\text { - Large confluent lesions encompassing several } \\
\text { spinal cord segments in up to } 30 \% \text { of patients } \\
\text { - Sometimes cord swelling }\end{array}$ \\
\hline MOG-AD & $\begin{array}{l}\text { - ADEM-typical: bilateral, poorly marinated and extensive lesions on T2-weighted and FLAIR } \\
\text { scans } \\
\text { - NMOsd-like lesions located in: brainstem, area postrema or around the third and fourth } \\
\text { ventricle as well as aqueduct } \\
\text { - MS-like lesions (also possible, but regarded as "red flags") } \\
\text { - Abnormalities on T2-weighted scans or on T1-weighted scans with enhancement in optic } \\
\text { nerves located anteriorly and encompassing }>1 / 2 \text { nerve length }\end{array}$ & $\begin{array}{l}\text { - T2-hyperintense longitudinally extensive, } \\
\text { continuous lesions comprising } \geq 3 \text { vertebral } \\
\text { segments } \\
\text { - Longitudinally extensive spinal cord atrophy } \\
\text { extending over } \geq 3 \text { contiguous vertebral } \\
\text { segments in patients with history of myelitis } \\
\text { - T2-hyperintense short spinal cord lesions } \\
\text { (<2 vertebral segments) }\end{array}$ \\
\hline
\end{tabular}


(Wingerchuk et al., 2015). This is supported by the fact that AQP4-IgG serum titres are about 500 times higher than in the CSF. It could be concluded that AQP4-IgG were formed mainly peripherally and then entered the CNS through the disrupted blood-brain barrier (BBB) (Jarius et al., 2010; Takahashi et al., 2007). On the other hand, intrathecal production of AQP4-IgG, particularly at the early stages of the disease, as well as the presence of AQP4-IgG restricted to the CSF could also occur (Bennett et al., 2009; Klawiter et al., 2009; Wingerchuk et al., 2015). Because of that, 2015 NMOsd criteria allow for evaluation of AQP4-IgG in the CSF in selected patients (Wingerchuk et al., 2015).

Importantly, AQP4-IgG seronegativity is observed in 10-25\% of NMOsd patients (Wingerchuk et al., 2007). In these cases, other antibodies might be present in serum, including MOG-Ab or antibodies against aquaporin 1 (AQP1-Ab) (Sato et al., 2014; Tzartos et al., 2013).

\section{Antibodies against myelin oligodendrocyte glycoprotein}

MOG-Ab could be present in the sera even in $21.1 \%$ of AQP4-IgG seronegative patients (Sato et al., 2014). However, these antibodies could also occur in other disorders, namely atypical MS (typically at low titres) or ADEM (Peschl et al., 2017). Recently, it was proposed that a new clinical entirety exists named MOG antibody-associated disease (MOG-AD), which includes various cases of CNS demyelination, mainly AQP4-IgG seronegative NMOsd, ADEM, isolated ON or myelitis with the presence of MOG-Ab in patients' sera as a main common feature (Ambrosius et al., 2020).

MOG-AD typical features include: relapsing (rarely monophasic) and milder disease course, a better recovery from relapses compared with NMOsd, a good response to steroids and plasma exchanges as well as to maintenance treatment with steroids, immunosuppressants or rituximab and the risk of deterioration after steroid discontinuation. Several MRI findings could be useful in making the diagnosis (Tab. 3) (Ambrosius et al., 2020).

\section{Other potential markers}

AQP1-Ab were detected in AQP4-IgG seronegative as well as seropositive NMOsd patients (Tzartos et al., 2013). However, $\mathrm{AQP1}-\mathrm{Ab}$ role as a new marker of NMOsd is questionable, as they could be also present in MS and serum levels might even be significantly higher in MS than in NMOsd (JasiakZatońska et al., 2022). Other potential markers useful in differential diagnosis are glial fibrillary acidic protein (GFAP) and interleukin-6 (IL-6), which are higher in the CSF of NMOsd cases vs. MS (Juryńczyk et al., 2015).

\section{Cerebrospinal fluid examination}

CSF analyses may support NMOsd diagnosis and typical findings are the following: pleocytosis over 50 cells $/ \mathrm{mm}^{3}$ (30-80\% of patients, particularly during relapse) with a high proportion of polymorphonuclear cells (a high proportion of neutrophils, possible presence of eosinophils), a high protein level of 100 to $500 \mathrm{mg} / \mathrm{dL}$ (25-30\% of patients) and the lack of oligoclonal bands (OCBs) (Wingerchuk, 2010; Wingerchuk et al., 2007). The presence of OCBs in the CSF is a red flag according to 2015 NMOsd diagnostic criteria, but does not exclude the diagnosis, as they could be present (usually temporarily though, during relapses) in 15-30\% of NMOsd patients (Juryńczyk et al., 2015; Wingerchuk et al., 2015, 2007).

In comparison, in MS the typical CSF characteristics include: normal or slightly elevated protein level, mild pleocytosis (less than 50 cells/ $\mu \mathrm{L}$ ) in $50 \%$ of cases with predomination of lymphocytes (90\%), elevated IgG concentration and the presence of OCBs (in approximately $95 \%$ of patients) (Deisenhammer et al., 2019; Juryńczyk et al., 2015).

\section{Other laboratory studies}

Other laboratory studies should also be performed to exclude alternative diagnoses, as presented in Tabs. 4 and 5 (Wingerchuk et al., 2015). Nevertheless, their results should

\begin{tabular}{|l|l|}
\hline Laboratory studies & $\begin{array}{l}\text { - Antibodies against aquaporin 4 (AQP4-IgG) } \\
\text { - Antibodies against myelin oligodendrocyte glycoprotein (MOG-Ab) } \\
\text { - Antinuclear antibodies (ANA) } \\
\text { - Anti-Borrelia IgM and IgG (ELISA and/or Western blot) }\end{array}$ \\
\begin{tabular}{ll|} 
- HIV testing \\
- Syphilis testing (Venereal Disease Research Laboratory, VDRL; rapid plasma reagin, RPR) \\
- Serum angiotensin converting enzyme or interleukin-2 receptor levels
\end{tabular} \\
\hline Cerebrospinal fluid examination & $\begin{array}{l}\text { - Cytosis, cell type, protein level } \\
\text { - Oligoclonal bands } \\
\text { - IgG index } \\
\text { - CSF/serum albumin ratio } \\
\text { - CSF PCR analysis, CSF serological tests, CSF microbiological tests (in selected patients) }\end{array}$ \\
\hline Magnetic resonance imaging (MRI) & $\begin{array}{l}\text { - MRI of the brain } \\
\text { - MRI of the optic nerves } \\
\text { - MRI of the spinal cord }\end{array}$ \\
\hline Others & $\begin{array}{l}\text { - Optical coherence tomography (OCT) } \\
\text { - Visual evoked potential (VEP) }\end{array}$ \\
\hline
\end{tabular}

Tab. 4. Investigative studies checklist 


\begin{tabular}{|c|c|c|}
\hline Disease & Main typical features & References \\
\hline Multiple sclerosis (MS) & $\begin{array}{l}\text { - Diagnosis based on clinical and radiological evidence of dissemination in space and in time, } \\
\text { according to } 2017 \mathrm{McD} \text { onald criteria } \\
\text { - OCBs present in the CSF of } 95 \% \text { of patients } \\
\text { - Brain lesions on MRI present in } 95 \% \text { of cases } \\
\text { - MRI of the spinal cord: short, multiple lesions }\end{array}$ & $\begin{array}{l}\text { Karussis, } 2014 ; \\
\text { Thompson } \\
\text { et al., } 2018\end{array}$ \\
\hline $\begin{array}{l}\text { Myelin oligodendrocyte } \\
\text { glycoprotein antibody-associated } \\
\text { disease (MOG-AD) }\end{array}$ & $\begin{array}{l}\text { - Various phenotypes including } 0 \mathrm{~N} \text {, isolated myelitis and LETM, ADEM, brainstem/cortical } \\
\text { encephalitis } \\
\text { - Relapsing (more commonly) or monophasic course } \\
\text { - Milder disease course than in NMOsd } \\
\text { - Presence of antibodies against myelin oligodendrocyte glycoprotein (MOG-Ab) } \\
\text { - MRI characteristics }\end{array}$ & Ambrosius et al., 2020 \\
\hline $\begin{array}{l}\text { Acute disseminated } \\
\text { encephalomyelitis (ADEM) }\end{array}$ & $\begin{array}{l}\text { - More common in paediatric population } \\
\text { - Often preceded by infection or vaccination } \\
\text { - Acute polyfocal neurological symptoms with encephalopathy } \\
\text { - Fever and seizures more common than in other CNS demyelinating disorders } \\
\text { - Usually monophasic course } \\
\text { - CSF: mild pleocytosis and elevated protein } \\
\text { - OCBs usually absent in the CSF } \\
\text { - Polyfocal, asymmetric, poorly marginated MRI lesions in the brain with partial/complete } \\
\text { resolution in follow-up MRI } \\
\text { - Confluent spinal cord lesions }\end{array}$ & Pohl et al., 2016 \\
\hline Idiopathic ON & $\begin{array}{l}\text { - Impaired visual acuity, visual field deficits, impaired colour vision, ocular pain } \\
\text { - In typical cases: good recovery in >90\% of patients } \\
\text { - Types: isolated ON (ION), relapsing isolated ON (RION), chronic relapsing ON (CRION) } \\
\text { - MRI without features of NMOsd, MS or MOG-AD }\end{array}$ & Kim et al., 2017 \\
\hline Idiopathic acute transverse myelitis & $\begin{array}{l}\text { - Bilateral symptoms/signs of the spinal cord dysfunction } \\
\text { - Rarely paroxysmal tonic spasms ( } 2 \% \text { vs. } 25 \% \text { in NMOsd) } \\
\text { - Evidence of inflammation of the spinal cord } \\
\text { - Progression in } 4 \text { hours to } 21 \text { days } \\
\text { - Exclusion of secondary inflammation and extra-axial compression of the spinal cord }\end{array}$ & $\begin{array}{l}\text { Transverse Myelitis Consortium } \\
\text { Working Group, } 2002\end{array}$ \\
\hline Systemic lupus erythematosus (SLE) & $\begin{array}{l}\text { - Neuropsychiatric SLE (NPSLE): several manifestations including 0N (7.3\%) and myelitis (4.9\%) } \\
\text { - Antinuclear antibodies (ANA) } \\
\text { - Anti-double-stranded DNA (anti-dsDNA) antibodies not always present in NPSLE }\end{array}$ & $\begin{array}{l}\text { Kim et al., 2017; } \\
\text { Mostafa } \\
\text { et al., } 2010 \\
\end{array}$ \\
\hline Sjögren's syndrome (SS) & $\begin{array}{l}\text { - Myelitis with LETM } \\
\text { - AQP4-IgG seropositivity, typical MRI findings and fulfilled criteria for NMOsd } \rightarrow \text { NMOsd coexisting } \\
\text { with SS }\end{array}$ & Kim et al., 2009 \\
\hline Neurosarcoidosis & $\begin{array}{l}\text { - Optic nerve involvement (also bilateral) } \\
\text { - Myelitis with LETM } \\
\text { - Systemic manifestation of sarcoidosis (bilateral hilar adenopathy, erythema nodosum, uveitis, } \\
\text { skin lesions) } \\
\text { - Elevated angiotensin converting enzyme } \\
\text { - Fluorodeoxyglucose positron emission tomography (FDG-PET) } \\
\text { - CSF findings: elevated protein level, pleocytosis (with prevalence of lymphocytes), } \\
\text { elevated lgG index, presence of OCBs } \\
\text { - Various, but not specific abnormalities on MRI: evidence of meningeal inflammation, } \\
\text { white matter lesions, periventricular T2-hyperintense lesions }\end{array}$ & $\begin{array}{l}\text { Kim et al., 2017; } \\
\text { Lacomis, 2011 }\end{array}$ \\
\hline Infections & $\begin{array}{l}\text { - Syphilis, Herpes simplex virus (HSV), Epstein-Barr virus (EBV), borreliosis, tuberculosis, } \\
\text { Mycoplasma pneumoniae, Streptococcus pneumoniae and others } \\
\text { - ON, LETM }\end{array}$ & Kim et al., 2017 \\
\hline Vascular malformation & $\begin{array}{l}\text { - Spinal dural arteriovenous fistula (SDAVF) - the most frequent vascular malformation } \\
\text { in the spinal cord } \\
\text { - Subacute and progressive myelopathy } \\
\text { - MRI: T2-hyperintense longitudinally extensive lesion in the spinal cord } \\
\text { - MRI differentiation features: abnormal dilated intradural veins on T2-weighted scans, serpentine } \\
\text { enhancing vascular structures on T1-weighted scans }\end{array}$ & Kim et al., 2017 \\
\hline CNS lymphoma & $\begin{array}{l}\text { - Variable MRI appearance of primary lymphoma could be confound with large, confluent } \\
\text { or tumefactive brain lesions in NMOsd } \\
\text { - Longitudinally extensive lesions in } 40 \% \text { of patients with spinal cord lymphoma } \\
\text { - CSF cytology, immunoglobulin heavy chain rearrangement testing and other molecular tests } \\
\text { - Positron emission tomography (PET) } \\
\text { - Histopathological confirmation is essential }\end{array}$ & Kim et al., 2017 \\
\hline
\end{tabular}

Tab. 5. Differential diagnosis of NMOsd 


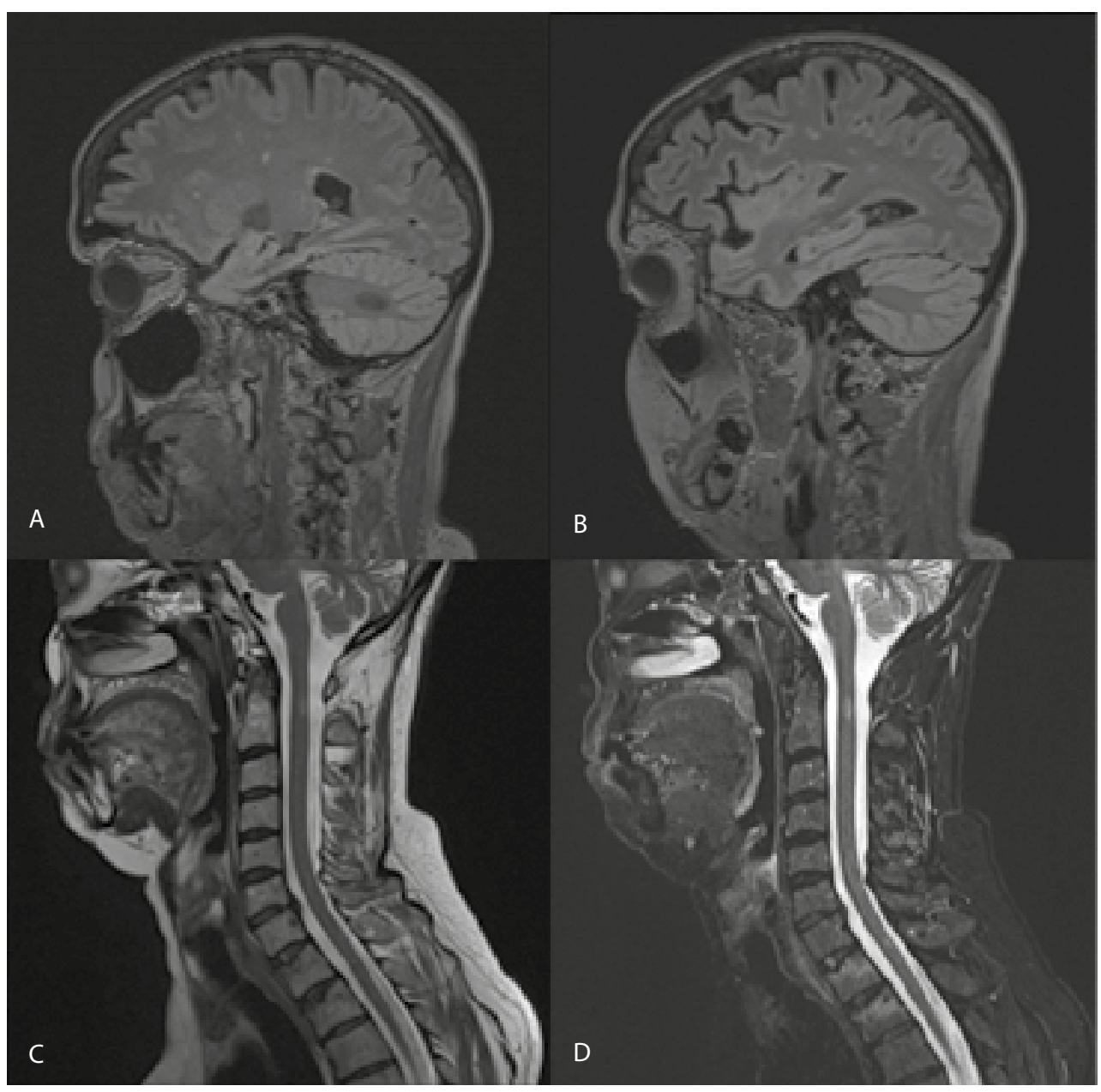

Fig. 3. 3T-MRI of the brain (A, B) and the spinal cord (C, D) in a 59-year-old woman with NMOsd and rheumatoid arthritis.

Case history: the first manifestation of the disease was spastic paresis of the lower limbs which occurred at the age of 57. MRI revealed intramedullary lesion at the level of Th1 and another one extending between half of Th6 to the upper border of Th8 vertebra, with gadoliniumenhancement and the spinal cord oedema (initially astrocytoma was suspected). The patient received steroids orally with partial improvement and further studies were ordered. MRI of the brain showed multiple supratentorial T2-hyperintense lesions (adjudicated as ischaemic). No lesions in the cervical spinal cord were found. Within a few months subsequent MRI of the thoracic spine showed lesions at the levels of Th1 and Th6-Th8 (as in the previous study) with inhomogenous enhancement, but without cord enlargement. CSF examination detected $4 \mathrm{WBC} / \mu \mathrm{L}$ and the protein level of $501 \mathrm{mg} / \mathrm{L}$; IgG index was 0.45 and the same pattern of OCBs was present in the CSF and in the serum. AQP4-IgG was positive. Chronic treatment with oral steroid was applied. Next year, following clinical observation, the diagnosis of NMOsd was made. Follow-up 3T MRI showed: (A, B) multiple FLAIR-hyperintense oval or round, supratentorial lesions; (C, D) T2-hyperintense short C2 lesions located posteriorly in the cervical spinal cord. At that time her EDSS was 6.5.

Diagnostic pitfall: symptoms of NMOsd could occur in patients with systemic autoimmune disorders and in these cases, OCBs could be present in both, the CSF and serum, but seropositivity for AQP4-IgG strongly promotes NMOsd diagnosis. Also, spinal cord lesions encompassing less than 3 vertebral segments and not necessarily fulfilling LETM definition might be found in NMOsd patients, especially in the beginning of the disease.

Abbreviations: AQP4-IgG - antibodies against aquaporin 4; CSF - cerebrospinal fluid; EDSS - Expanded Disability Status Scale; LETM - longitudinally extensive transverse myelitis; MRI - magnetic resonance imaging; NMOsd - neuromyelitis optica spectrum disorder; $\mathbf{O C B}$ - oligoclonal bands; $\mathbf{W B C}$ - white blood cells 
be interpreted with caution and in the context of other clinical and radiographic characteristics. Importantly, systemic autoimmune diseases, e.g. SLE, could lead to various neurological complications, including $\mathrm{ON}$ or myelitis, or coexist with AQP4-IgG seropositive NMOsd (Fig. 3) (Kim et al., 2017). Moreover, antinuclear autoantibodies (ANA) are present in about $50 \%$ of NMOsd patients, sometimes without clinical symptoms of a systemic autoimmune disorder (Wingerchuk et al., 2007).

\section{NEUROIMAGING PITFALLS}

\section{MRI of the brain and the optic nerves}

Classically the initial brain MRI is considered to be normal in NMOsd, except for the presence of gadolinium enhancement of the optic nerves or brainstem lesions in a subset of patients (Wingerchuk, 2010; Wingerchuk et al., 2007). In the optic nerves, MRI abnormalities suggestive of NMOsd include: longitudinally extensive gadolinium-enhancing lesions (proposed cut-off value: $17.6 \mathrm{~mm}$ ), posterior location and/or the optic chiasm involvement and simultaneous bilateral presentation. On the contrary, in MS focal shorter and anteriorly located lesions are observed (Khanna et al., 2012; Mealy et al., 2015).

Nevertheless, abnormalities in initial brain MRI may in fact be present in 43-70\% of NMOsd cases, their frequency increases within the duration of the disease and in follow-up MRIs $51-89 \%$ of patients have brain lesions, which typically do not fulfil MS criteria (Kim et al., 2015; Wingerchuk, 2010; Wingerchuk et al., 2007). In NMOsd MRI lesions are usually located in the regions characterised by high AQP4 expression, but other areas can be involved as well. Typical localisations include: dorsal brainstem, diencephalon, adjacent to the third ventricle and aqueduct, the areas surrounding the lateral ventricles, cerebral hemispheres, and corticospinal tracts (Tab. 3). Gadolinium-enhancing brain lesions could be present in about 9-36\% of NMOsd patients. The typical enhancement pattern is "cloud-like" in contrast to ovoid, ring or open-ring enhancement in MS. Other abnormalities visualised following gadolinium administration include: "pencil-thin" enhancement of the ependyma lining of the lateral ventricles and, rarely, meningeal or well-marginated nodular enhancement (Kim et al., 2015).

However, interpretation of MRI findings needs particular caution, as in a subset of patients follow-up MRI may reveal brain abnormalities meeting MS diagnostic criteria (10-16\% of NMOsd or even 27\% of AQP4-IgG seropositive NMOsd cases) (Matthews et al., 2013; Wingerchuk, 2010; Wingerchuk et al., 2007). Furthermore, lesions in locations typical for NMOsd could also be observed in MS. The criteria, which allow for distinction of relapsing-remitting MS (RRMS) from NMOsd with $92 \%$ sensitivity and $96.2 \%$ specificity include: at least one T2 lesion in both, neighbouring to the body of the lateral ventricle and in the inferior temporal lobe or either subcortical
Ultra-high-field 7 Tesla MRI could provide additional information including the presence of rim-like or nodular paramagnetic MRI phase changes, or visible vein in the centre of a lesion, which are typical for MS, but rarely found in NMOsd lesions (Sinnecker et al., 2016). Also MR spectroscopy (MRS) could facilitate the distinction between NMOsd and MS, as in NMOsd lesions myoinositol is decreased, while in MS there is a reduction of $\mathrm{N}$-acetylaspartate (NAA) (Kim et al., 2015).

\section{MRI of the spinal cord}

MRI of the spinal cord may reveal T2-weighted longitudinal, continuous lesions comprising at least three vertebral segments, which are $98 \%$ sensitive and $83 \%$ specific for NMOsd (Wingerchuk, 2010; Wingerchuk et al., 2006). Their presence is considered the most specific radiological feature differentiating NMOsd from MS (Tab. 3) (Kim et al., 2015). Other typical MRI findings in acute myelitis include: central location with grey matter involvement, gadolinium enhancement on T1-weighted sequence, rostral extension of the cervical spinal cord lesion into the brainstem, cord swelling, decreased signal on T1-weighted sequences corresponding to regions of increased T2-weighted signal (Kim et al., 2015; Wingerchuk et al., 2015). In chronic myelitis longitudinally extensive spinal cord atrophy may occur and correlates with disability measured by Expanded Disability Status Scale (EDSS) (Asgari et al., 2013).

Although spinal cord lesions extending across at least three vertebral segments are very typical for NMOsd, their appearance in MRI is time dependent. Specifically, they may not develop fully shortly after disease onset as well as reduce or resolve over time (Lalan et al., 2012; Wingerchuk et al., 2015). Therefore, shorter lesions may sometimes be observed when is MRI done in the first days of relapse, in remission or following high-dose steroids infusions (Fig. 3) (Asgari et al., 2013; Lalan et al., 2012). It was shown that in AQP4-IgG seropositive NMOsd with the initial myelitis presentation short lesions ( $<3$ vertebral segments) in the spinal cord were found in $14 \%$ of patients and in $40 \%$ it led to the misdiagnosis of MS, delaying NMOsd diagnosis and appropriate treatment (Flanagan et al., 2015). Although central spinal cord involvement is characteristic for NMOsd myelitis, peripheral lesions were also observed in a subset of patients (Lalan et al., 2012).

Gadolinium-enhancement is present in $94 \%$ of NMOsd myelitis attacks and the most common type of enhancement is a patchy pattern. Nevertheless, ring-enhancement was observed in $32 \%$ of NMOsd patients with myelitis and its resolution was noticed in $47 \%$ of cases within 1 month. Importantly, such pattern of enhancement allows distinction of NMOsd from other longitudinally extensive myelopathies, e.g. sarcoidosis, spondylotic myelopathy, dural arteriovenous fistula, infarction and paraneoplastic myelopathy. Nonetheless, ring-enhancement does not distinguish NMOsd from MS, as such pattern was observed in 6.2-20\% 
of MS cases with spinal cord lesions. However, coexisting T2-hyperintense longitudinally extensive lesions present in $88 \%$ of NMOsd cases was a clear differentiating feature (Zalewski et al., 2017).

\section{SUMMARY}

In clinical practice the distinction between NMOsd and MS is not always perfectly clear, making the early and appropriate diagnosis particularly challenging. Therefore, clinical features, laboratory studies (AQP4-IgG, MOG-Ab) and MRI scans should be carefully analysed in each patient with a neurological syndrome and white matter lesions in the brain and/or in the spinal cord. Follow-up investigative studies should be considered in selected situations, e.g. atypical, undetermined cases or without appropriate therapeutic response, as accurate diagnosis is crucial to provide prognosis and adequate treatment.

\section{Conflict of interest}

The authors declare no financial or private association with other persons or organisations, which could negatively influence the content of this paper or claim rights for it.

\section{Acknowledgments}

The authors wish to acknowledge Mikotaj Pawlak, MD, PhD, for his insights and work on MRI studies in NMOsd patients.

\section{References}

Ambrosius W, Michalak S, Kozubski W et al.: Myelin oligodendrocyte glycoprotein antibody-associated disease: current insights into the disease pathophysiology, diagnosis and management. Int J Mol Sci 2020; 22: 100.

Asgari N, Skejoe HPB, Lillevang ST et al.: Modifications of longitudinally extensive transverse myelitis and brainstem lesions in the course of neuromyelitis optica (NMO): a population-based, descriptive study. BMC Neurol 2013; 13: 33.

Avasarala J, Pettigrew C, Sutton P et al.: Can a diagnosis of multiple sclerosis be made without ruling out neuromyelitis optica spectrum disorder? Mult Scler Relat Disord Elsevier 2020; 40: 101949.

Bennett JL, Lam C, Kalluri SR et al.: Intrathecal pathogenic anti-aquaporin-4 antibodies in early neuromyelitis optica. Ann Neurol 2009; 66: 617-629.

Bichuetti DB, de Camargo AS, Falcão AB et al.: The retinal nerve fiber layer of patients with neuromyelitis optica and chronic relapsing optic neuritis is more severely damaged than patients with multiple sclerosis. J Neuroophthalmol 2013; 33: 220-224.

Cohen M, De Sèze J, Marignier R et al.: False positivity of anti aquaporin-4 antibodies in natalizumab-treated patients. Mult Scler 2016; 22: 1231-1234.

Deisenhammer F, Zetterberg H, Fitzner B et al.: The cerebrospinal fluid in multiple sclerosis. Front Immunol 2019; 10: 726.

Flanagan EP, Weinshenker BG, Krecke KN et al.: Short myelitis lesions in aquaporin-4-IgG-positive neuromyelitis optica spectrum disorders. JAMA Neurol 2015; 72: 81-87.

Gelfand JM, Cotter J, Klingman J et al.: Massive CNS monocytic infiltration at autopsy in an alemtuzumab-treated patient with NMO. Neurol Neuroimmunol Neuroinflamm 2014; 1: e34.
Hamid SH, Elsone L, Mutch K et al.: The impact of 2015 neuromyelitis optica spectrum disorders criteria on diagnostic rates. Mult Scler 2017; 23: 228-233.

Jarius S, Aboul-Enein F, Waters P et al.: Antibody to aquaporin-4 in the long-term course of neuromyelitis optica. Brain 2008; 131: 3072-3080.

Jarius S, Franciotta D, Paul F et al.: Cerebrospinal fluid antibodies to aquaporin-4 in neuromyelitis optica and related disorders: frequency, origin, and diagnostic relevance. J Neuroinflammation 2010; 7: 52.

Jasiak-Zatońska M, Michalak S, Osztynowicz K et al.: Relationship between blood-brain permeability and antibodies against aquaporins in neuromyelitis optica spectrum disorders and multiple sclerosis patients. Neurol Neurochir Pol 2022. DOI: 10.5603/PJNNS. a2022.0007.

Juryńczyk M, Craner M, Palace J: Overlapping CNS inflammatory diseases: differentiating features of NMO and MS. J Neurol Neurosurg Psychiatry 2015; 86: 20-25.

Juryńczyk M, Jakuszyk P, Kurkowska-Jastrzębska I et al.: Increasing role of imaging in differentiating MS from non-MS and defining indeterminate borderline cases. Neurol Neurochir Pol 2021. DOI: 10.5603/PJNNS.a2021.0077.

Juryńczyk M, Weinshenker B, Akman-Demir G et al.: Status of diagnostic approaches to AQP4-IgG seronegative $\mathrm{NMO}$ and NMO/MS overlap syndromes. J Neurol 2016; 263: 140-149.

Karussis D: The diagnosis of multiple sclerosis and the various related demyelinating syndromes: a critical review. J Autoimmun 2014; 48-49: 134-142.

Khanna S, Sharma A, Huecker J et al.: Magnetic resonance imaging of optic neuritis in patients with neuromyelitis optica versus multiple sclerosis. J Neuroophthalmol 2012; 32: 216-220.

Kim HJ, Paul F, Lana-Peixoto MA et al.; Guthy-Jackson Charitable Foundation NMO International Clinical Consortium \& Biorepository: MRI characteristics of neuromyelitis optica spectrum disorder: an international update. Neurology 2015; 84: 1165-1173.

Kim SM, Kim SJ, Lee HJ et al.: Differential diagnosis of neuromyelitis optica spectrum disorders. Ther Adv Neurol Disord 2017; 10: 265-289.

Kim SM, Waters P, Vincent A et al.: Sjögren's syndrome myelopathy: spinal cord involvement in Sjögren's syndrome might be a manifestation of neuromyelitis optica. Mult Scler 2009; 15: 1062-1068.

Klawiter EC, Alvarez E $3^{\text {rd }}$, Xu J et al.: NMO-IgG detected in CSF in seronegative neuromyelitis optica. Neurology 2009; 72: 1101-1103.

Lacomis D: Neurosarcoidosis. Curr Neuropharmacol 2011; 9: 429-436.

Lalan S, Khan M, Schlakman B et al.: Differentiation of neuromyelitis optica from multiple sclerosis on spinal magnetic resonance imaging. Int J MS Care 2012; 14: 209-214.

Matthews L, Marasco R, Jenkinson M et al.: Distinction of seropositive NMO spectrum disorder and MS brain lesion distribution. Neurology 2013; 80: 1330-1337.

Mealy MA, Whetstone A, Orman G et al.: Longitudinally extensive optic neuritis as an MRI biomarker distinguishes neuromyelitis optica from multiple sclerosis. J Neurol Sci 2015; 355: 59-63.

Mostafa GA, Ibrahim DH, Shehab AA et al.: The role of measurement of serum autoantibodies in prediction of pediatric neuropsychiatric systemic lupus erythematosus. J Neuroimmunol 2010; 227: 195-201.

Naismith RT, Tutlam NT, Xu J et al.: Optical coherence tomography differs in neuromyelitis optica compared with multiple sclerosis. Neurology 2009; 72: 1077-1082.

Neto SP, Alvarenga RM, Vasconcelos CC et al.: Evaluation of patternreversal visual evoked potential in patients with neuromyelitis optica. Mult Scler 2013; 19: 173-178.

Peschl P, Bradl M, Höftberger R et al.: Myelin oligodendrocyte glycoprotein: deciphering a target in inflammatory demyelinating diseases. Front Immunol 2017; 8: 529.

Pohl D, Alper G, Van Haren K et al.: Acute disseminated encephalomyelitis: updates on an inflammatory CNS syndrome. Neurology 2016; 87 (Suppl 2): S38-S45. 
Sato DK, Callegaro D, Lana-Peixoto MA et al.: Distinction between MOG antibody-positive and AQP4 antibody-positive NMO spectrum disorders. Neurology 2014; 82: 474-481.

Selmaj K, Selmaj I: Novel emerging treatments for NMOSD. Neurol Neurochir Pol 2019; 53: 317-326.

Sinnecker T, Schumacher S, Mueller K et al.: MRI phase changes in multiple sclerosis vs neuromyelitis optica lesions at 7T. Neurol Neuroimmunol Neuroinflamm 2016; 3: e259.

Solomon AJ, Bourdette DN, Cross AH et al.: The contemporary spectrum of multiple sclerosis misdiagnosis: a multicenter study. Neurology 2016; 87: 1393-1399.

Suthiphosuwan S, Oh J, Bharatha A: Clinical pitfall: false-positive aquaporin-4 IgG leading to misdiagnosis of neuromyelitis optica spectrum disorder in patient with spinal arteriovenous fistula. Spinal Cord Ser Cases 2017; 3: 17030.

Takahashi T, Fujihara K, Nakashima I et al.: Anti-aquaporin-4 antibody is involved in the pathogenesis of NMO: a study on antibody titre. Brain 2007; 130: 1235-1243.

Thompson AJ, Banwell BL, Barkhof F et al.: Diagnosis of multiple sclerosis: 2017 revisions of the McDonald criteria. Lancet Neurol 2018; 17: $162-173$

Transverse Myelitis Consortium Working Group: Proposed diagnostic criteria and nosology of acute transverse myelitis. Neurology 2002; 59: 499-505.
Tzartos JS, Stergiou C, Kilidireas K et al.: Anti-aquaporin-1 autoantibodies in patients with neuromyelitis optica spectrum disorders. PLoS One 2013; 8: e74773.

Waters P, Vincent A: Detection of anti-aquaporin-4 antibodies in neuromyelitis optica: current status of the assays. Int MS J 2008; 15: 99-105.

Waters PJ, Pittock SJ, Bennett JL et al.: Evaluation of aquaporin-4 antibody assays. Clin Exp Neuroimmunol 2014; 5: 290-303.

Wingerchuk DM: Neuromyelitis optica spectrum disorders. Continuum (Minneap Minn) 2010; 16: 105-121.

Wingerchuk DM, Weinshenker BG: Neuromyelitis optica spectrum disorder diagnostic criteria: sensitivity and specificity are both important. Mult Scler 2017; 23: 182-184.

Wingerchuk DM, Banwell B, Bennett JL et al.: International consensus diagnostic criteria for neuromyelitis optica spectrum disorders. Neurology 2015; 85: 177-189.

Wingerchuk DM, Lennon VA, Lucchinetti CF et al.: The spectrum of neuromyelitis optica. Lancet Neurol 2007; 6: 805-815.

Wingerchuk DM, Lennon VA, Pittock SJ et al.: Revised diagnostic criteria for neuromyelitis optica. Neurology 2006; 66: 1485-1489.

Zalewski NL, Morris PP, Weinshenker BG et al.: Ring-enhancing spinal cord lesions in neuromyelitis optica spectrum disorders. J Neurol Neurosurg Psychiatry 2017; 88: 218-225. 